\title{
Response of ants and spiders to prescribed fire in oak woodlands of California
}

\author{
Emma C. Underwood · James F. Quinn
}

Received: 26 August 2009/ Accepted: 7 January 2010/Published online: 29 January 2010

(C) The Author(s) 2010. This article is published with open access at Springerlink.com

\begin{abstract}
Conservation managers of oak woodlands have been reintroducing fire both as an ecological process per se and to assist in restoring native plant communities. To increase our understanding of the impacts of reintroduced fire on ground-dwelling invertebrates we examined the response of ants and spiders to a late season (autumn) prescribed fire conducted in a blue oak (Quercus douglasii) woodland ecosystem in northern California. Twelve $100 \mathrm{~m} \times 100 \mathrm{~m}$ plots were established, six plots received a burn treatment and the remaining six plots were unburned controls. Ants and spiders were sampled using pitfall traps left open continuously and collected approximately every 32 days. Sampling was conducted over a year, consisting of four pre-burn and nine post-burn collections. Abundance was analyzed using a repeated measures ANOVA, which showed seed-harvester ants decreased significantly in the two months following the fire. Total spider abundance also showed a significant decrease in two months, although this did not occur immediately after the burn. One spider hunting guild, the 'diurnal ambush' group (Thomisidae) remained suppressed for up to nine months. Correspondence analysis measures of ant species abundance with environmental and vegetation variables (percent rock, bare ground, plant species richness and height of herbaceous vegetation) were higher than expected by chance, which assists in explaining some of the responses. Findings from this study revealed that the reintroduction of autumn burns has modest and short-term effect on the invertebrates sampled, suggesting that late season fires are compatible with other conservation goals for oak woodland ecosystems.
\end{abstract}

E. C. Underwood $(\bowtie) \cdot$ J. F. Quinn

Department of Environmental Science and Policy, University of California, One Shields Avenue, Davis, CA 95616-8571, USA

e-mail: eunderwoodrussell@ucdavis.edu
Keywords Burning - Conservation management . Ecological disturbance $\cdot$ Functional groups $\cdot$ Invertebrates . Restoration

\section{Introduction}

California's oak woodlands are some of the most biologically diverse natural communities in the state, harboring over 300 vertebrate species including a number of endangered species. Fire is one of the defining characteristics of these ecosystems and the importance of restoring fire as a landscape process where historical fire regimes have been altered or eliminated has been widely recognized (Biswell 1989; Jepson 1910; Parsons and van Wagtendonk 1996). The re-establishment of fire has been further encouraged through its use as a restoration tool to manage the plant community, most notably to control invasive species, discourage the growth of woody species, and encourage the performance of native grasses and forbs (Baker 1994; Curtis and Partch 1948). Monitoring the effects of such practices has focused largely on vascular plants (Klinger and Messer 2000; Peterson and Reich 2001), consequently the effects of fire on the invertebrate community are not fully understood.

This gap in knowledge is particularly important since invertebrates are critical to processes such as decomposition, herbivory, and pollination, and provide important dietary linkages between different trophic levels (Hölldobler and Wilson 1990; Lal 1988). In addition, ground dwelling invertebrate species can often be clustered into functional groups based on diet or hunting strategy which can provide valuable surrogates for harder-to-measure components of the ecosystem. For instance, they can be used to make inferences on habitat quality with respect to microenvironmental and 
biotic features, giving useful information for monitoring post-burn conditions (McIver et al. 1992; Uetz 1979). Studies which have analyzed the impacts of prescribed fire on invertebrates have recorded a range of responses from minor, ephemeral effects (Abbott 1984; Abbott et al. 2003; Majer 1983) to substantial reductions of invertebrate populations across a range of habitats (Andersen 1991; Reichert and Reeder 1970). For example, Abbott et al. (2003) found spiders to be resilient to burning in a Eucalyptus forest in Australia, compared to other research reporting either postburn increases in vagrant, desiccation-tolerant spiders, or decreases in spiders dependent on vegetation for web construction (Reichert and Reeder 1970). This range of responses results from a complex interaction of season, frequency and intensity of burning, species level adaptations to fire (e.g., burn tolerance, recolonization potential), and the stage of organism's life cycle exposed to the burn (Vanderwoude et al. 1997).

We report on the impacts of late season prescribed fire in an oak woodland to assist conservation managers understand the impacts of reintroducing fire on invertebrates. This work compliments another study (Underwood and Christian 2009) designed to examine the effects of early season (spring) prescribed fires specifically aimed at controlling invasive plants. Early season fires are timed to follow the seed set of most native winter annuals, but precede seed set of noxious introduced species, such as yellow starthistle (Centauria solstitialis) and a variety of Mediterranean grasses (e.g., Bromus spp.). While early season fires are important for management, they are relatively small in scale and occur when plants are still green and flammability is low. Consequently these fires do not effectively mimic the natural fire cycle of Western grasslands and oak woodlands where frequent large fires occurred after seed set and annuals are cured. Given that invertebrate communities are known to be highly seasonal (e.g., Whitford 1978) and likely to be adapted to late season fire, if the reintroduction of natural fire is a conservation goal it is also important to explore the responses to autumn fires.

In this study, we document the effects of late-season fires on ants (Hymenoptera: Formicidae), which are the numerically dominant macroinvertebrates in this system, and spiders (Araneae), which are the dominant invertebrate predator group. Both are also abundant and reasonably diverse, so they are readily sampled and classified. For these reasons, they are thought to be attractive indicator taxa for changes in diversity as well as more general impacts on the overall invertebrate community (Alonso 2000). We also examine the extent to which responses to burning can be explained by their association with fine scale habitat variables.

\section{Methods}

Study site

This study was conducted at The Nature Conservancy's Dye Creek Preserve $(15,000$ ha) located in the Lassen Foothills in northern California, which represents California's largest stand of blue oak (Quercus douglasii) woodland in conservation ownership (The Nature Conservancy 2000). The elevation of the preserve ranges from $60-750 \mathrm{~m}$ with thin, volcanic soils and many rocky outcrops and a distinctly Mediterranean climate, characterized by dry, hot summers and wet winters. Oak coverage is patchy, with a scattered understory of buckbrush (Ceanothus cuneatus) and manzanita (Arctostaphylos spp.) and an herbaceous layer consisting predominantly of non-native forbs and grasses. Grazing is allowed on the preserve between November and April (approximately 1 cow-calf pair per 4.5 ha) with hunting activities in the autumn and spring.

Lightning caused wildfires, as well as historical anthropogenic burning by Native Americans, would have occurred predominantly in the autumn (Barbour et al. 1993; Lewis 1995). Since lightning strikes vary both spatially and temporally, the natural state of the ecosystem is one of consistent variability. Prescribed fire has been adopted as a broad-scale management tool on the preserve (The Nature Conservancy 2000) and a portion of the preserve is burned each year (e.g., 273 ha in 2002 and 699 ha in 2003). The area of the experimental plots, however, had not been burned in over 30 years, resulting in an artificially stabilized system.

\section{Experimental design}

To evaluate the effects of fire season on invertebrates we used a randomized complete block design consisting of six blocks each containing two $100 \mathrm{~m} \times 100 \mathrm{~m}$ plots; one of which received an autumn (late season) burn, the other representing the unburned control. The location of plots was stratified by elevation (335-381 m), slope $\left(0-10^{\circ}\right)$, and aspect (east to west facing slopes). Reference to digital orthophoto quads (taken in 1993) ensured that 25-50\% of the plot was covered by mature oak tree canopy. Invertebrates were sampled using pitfall traps consisting of six plastic cups per plot, filled with a 50\% ethylene glycol and water solution, and sheltered by a supported cover to minimize dilution by rain. To reduce the detection of edge effects, the first pitfall trap was placed in the center of the plot $(50 \mathrm{~m}$ from each edge) and the remaining five at random distances (between 10-25 m) and cardinal directions (eight classes) from the center (Trueman and Cranston 1994). 
Pitfall traps were open continuously and collected on average every 32 days, with a 15 day sample directly before and after each of the burns to capture immediate invertebrate responses. Invertebrates were sampled over one year; consisting of four pre-burn collections (July, August, September, and October 2002) and nine post-burn collections (November 2002 to July 2003). Although the limitations of pitfall sampling are recognized, for example the 'trappability effect' of removing vegetation in burned sites (Melbourne 1999; Uetz and Unzicker 1976), pitfall catches do reflect the relative population levels of mobile ground dwelling invertebrates and also permit continuous sampling of temporally stratified species (Neumann 1991; Uetz 1979). After collection, pitfall catches were washed and sorted to provide composition and abundance data for each pitfall trap. Ants were identified to species and spiders to family and subfamily and specimens were preserved in $95 \%$ ethanol.

To characterize the environment around each pitfall trap, selected habitat variables and plant species composition were sampled in control plots in May 2003. Habitat variables were measured within a $150 \mathrm{~cm} \times 150 \mathrm{~cm}$ square centered on each pitfall trap and consisted of: $\%$ rock, $\%$ wood, $\%$ cow pat, $\%$ bare ground, $\%$ litter, and distance to nearest oak tree. Vegetation composition data was taken within a $30 \mathrm{~cm} \times 30 \mathrm{~cm}$ square randomly placed three times (non-overlapping) within the larger square. Vegetation measurements included identification and estimation of species cover using eight cover classes (Bailey and Poulton 1968) and five measurements of herbaceous height within each square. Summary vegetation data around each pitfall trap consisted of: total plant species richness, average height of the herbaceous layer, average $(\%)$ cover of each species, and average cover by plant functional groups: $\%$ cover non-native forbs, $\%$ cover native forbs, $\%$ cover non-native grasses, and $\%$ cover native grasses.

Experimental burns were conducted on 17 and 18 October 2002 (three plots per day) with temperature and wind speed being similar on both days. Herbaceous vegetation was fully cured at the end of the growing season and an average of $87 \%$ of the understory vegetation of plots was burned, exceptions were immediately around oak trees where moisture was higher. Pitfall traps were re-set immediately after each fire.

\section{Data analysis}

Ant species were divided into two diet-based functional groups: seed-harvesters/scavengers and omnivores (Kaspari 2000). Spider families and subfamilies were grouped according to hunting guilds (McIver et al. 1992; Niwa and Peck 2002; Post and Reichert 1977). Only five of the eight spider groups, however, were sufficiently abundant to be analyzed statistically: Diurnal Ambush (Thomisidae), Diurnal Pursuit (Lycosidae), Diurnal Stalk (Salticidae), Nocturnal Running (Gnaphosidae), and the only trapping group, Funnel Web (Agelenidae). Expected catches for destroyed pitfall traps (e.g., from cattle damage) were estimated by averaging the contents of the remaining pitfalls within that plot and overall plot abundances were calculated by combining the six pitfall traps within each plot. For both ants and spiders abundance data were log transformed $\left(\log _{\mathrm{e}}\right.$ count +1$)$ and resulting distributions were tested to ensure that they approximated normal distributions (Shapiro-Wilk).

To analyze fire effects a repeated-measures ANOVA (Profile Analysis) was performed (von Ende 2001). The dependent variables used in the analyses included the total abundance of ants, spiders, and abundance by their respective functional groups. The Profile Analysis transformed the within-subject repeated measure (month) data to a series of contrasts to test for a burn effect, month effect, and burn-by-month interaction, and finally performed univariate analyses to assess whether there were between-treatment differences in abundance by month (von Ende 2001) (using proc GLM; SAS 1999). Where necessary, data were adjusted against violations of sphericity by using the Huynh-Feldt (H-F) adjustment. Results where $P<0.05$ are reported as statistically significant, and values of $0.05<P<0.1$ are also examined, since these may have ecological relevance and be of practical importance for land managers (Martínez-Abrain 2007).

To visualize species abundances in relation to environmental variables and determine the correlation among these factors, we conducted a Canonical Correspondence Analysis (CCA) (ter Braak 1995). We analyzed habitat and vegetation variables with the $\left(\log _{\mathrm{e}}\right)$ abundance of ant species and then spider groups recorded from the control pitfall trap collections from June and July 2003. The premise was to identify species associations in the natural environment (unburned) that might assist in the interpretation of responses to fire. Because of the seasonal variation in invertebrate abundances, we selected two adjacent months that received no precipitation, were of relatively similar average temperatures, and reflected peak foraging activity for the many ant species, thereby optimizing the potential for detecting relationships with respect to environmental characteristics. Pitfall trap scores were centered and standardized to unit variance, and the ordination was performed to optimize the configuration of species rather than pitfalls. Monte Carlo tests were conducted to test the null hypothesis that there was no relationship between the species abundance and environmental variable matrices (999 permutations) (using PCORD version 4.14 (McCune and Mefford 1999)). 


\section{Results}

Sixteen species of ants were recorded at the site (Table 1); five seed-harvesters/scavengers and ten omnivores. The abundances of two ant species Pheidole californica and Pheidole creightoni were combined owing to difficulties in distinguishing them, particularly since they hybridize (Burge 2005). Messor andrei was by far the most abundant ant collected at the site, with Prenolepis imparis (the winter ant) and Dorymyrmex insanus the rarest. Three spider families, Salticidae, Gnaphosidae, and Thomisidae had approximately equal abundance of individuals, while the Funnel Web group Agelenidae was least numerous. A strong seasonal effect was observed in all groups over the year (Fig. 1a-c).

Profile Analyses for all groups showed a highly significant effect of time (month) over the 13 collections $(P<0.0001)$ reflecting seasonal variations in invertebrate abundance. Results for the four pre-burn collections for both ant and spider groups confirmed that there were no significant differences between burn and control plots before treatment. Using total ant abundance a significant burn-by-month interaction was detected $(F=2.66$, $\mathrm{df}=12$, H-F $P=0.009$ ), but did not reveal a measurable burn effect when analyzed over all months. The contrast analysis revealed a significant decrease in total ant abundance between the immediate pre-burn and first post-burn samples $(F=5.34$, df $=1, P=0.043)$ and also in the subsequent collection $(F=5.92, \quad \mathrm{df}=1, \quad P=0.035)$
(Fig. 1a). A more detailed analysis by functional group showed a decrease in the seed-harvesters, displaying a significant burn-by-month interaction $(F=3.34$, df $=12$, $P=0.002)$, which reflected the same pattern-declining significantly between the immediate pre- and post-burn samples $(F=6.24$, df $=1, P=0.032)$ and again in the second post-burn month (December) $(F=13.49$, df $=1$, $P=0.004)$. No response was detected for the omnivore group.

The Profile Analysis using abundance of all five spider groups revealed a significant burn effect $(F=7.87$, df $=1, P=0.019)$ and also burn-by-month interaction $(F=2.55, \mathrm{df}=12, P=0.014)$ (Fig. 1b). This decrease in burn plot abundance was not in the immediate post-burn collection but rather in the second (December) and third (January) collections $(F=24.60, \mathrm{df}=1, P=0.0006$ and $F=6.33$, df $=1, P=0.031$ respectively). The Diurnal Ambush hunting guild showed the most dramatic response, decreasing significantly in both burn-by-month interaction $(F=2.70$, df $=12, P=0.036)$ and overall burn effect ( $F=9.06$, df $=1, P=0.013$ ) (Fig. 1c). A notable decline in burn-plot abundance was detected in the first post-burn collection $(F=3.61$, df $=1, P=0.087)$, which became highly significant in the second post-burn collection (December; $F=28.49$, df $=1, P=0.0003$ ). There was no genuine recovery for this group up to nine months after the burn. The only other spider group to show a notable decrease after the burn treatment was the Nocturnal Running group, with a marginally significant burn effect
Table 1 Summary of ants and spiders caught in all pitfall samples between July 2002 and July 2003 at the Dye Creek Preserve, northern California

Functional group codes are: $O$ omnivore, $S H$ seed-harvester/ scavenger, $D S$ diurnal stalk, $N R$ nocturnal running, $D A$ diurnal ambush, $D P$ diurnal pursuit, and $F W$ funnel web

\begin{tabular}{llll}
\hline $\begin{array}{l}\text { Ant subfamily or } \\
\text { spider family }\end{array}$ & $\begin{array}{l}\text { Ant species or spider } \\
\text { hunting guild }\end{array}$ & Code & $\begin{array}{l}\text { Functional } \\
\text { group }\end{array}$ \\
\hline Myrmicinae & Messor chicoensis & meschi & SH \\
Myrmicinae & Pheidole californica/creightoni & phecc & SH \\
Myrmicinae & Pheidole hyatti & phehya & SH \\
Myrmicinae & Solenopsis xyloni & solxyl & SH \\
Myrmicinae & Solenopsis molesta & solmol & $\mathrm{O}$ \\
Myrmicinae & Leptothorax nevadensis & lepnev & $\mathrm{O}$ \\
Myrmicinae & Leptothorax andrei & lepand & $\mathrm{O}$ \\
Formicinae & Camponotus semitestaceus & camsem & $\mathrm{O}$ \\
Formicinae & Formica moki & formok & $\mathrm{O}$ \\
Formicinae & Brachymyrmex depilis & bradep & $\mathrm{O}$ \\
Formicinae & Camponotus essigi & camess & $\mathrm{O}$ \\
Formicinae & Prenolepis impairs & preimp & $\mathrm{O}$ \\
Dolichoderinae & Tapinoma sessile & tapses & $\mathrm{O}$ \\
Dolichoderinae & Dorymyrmex insanus & dorins & $\mathrm{O}$ \\
Salticidae & Diurnal stalk & diusta & DS \\
Gnaphosidae & Nocturnal running & nocrun & NR \\
Thomisidae & Diurnal ambush & diuamb & DA \\
Lycosidae & Diurnal pursuit & diupur & DP \\
Agelenidae & Funnel web & funweb & FW \\
\hline
\end{tabular}


Fig. 1 Comparison of burn and control plots for total abundance (mean $+1 \mathrm{SE}, n=12$ plots) from experimental burns conducted at the Dye Creek Clockwise from top left: a all ants, b all spiders, $\mathbf{c}$ Diurnal Ambush (Thomisidae) spider hunting guild. Months are approximate. Legend for treatment: control plots (Circles in black), burn plots ( $x$ in grey) Preserve, northern California.
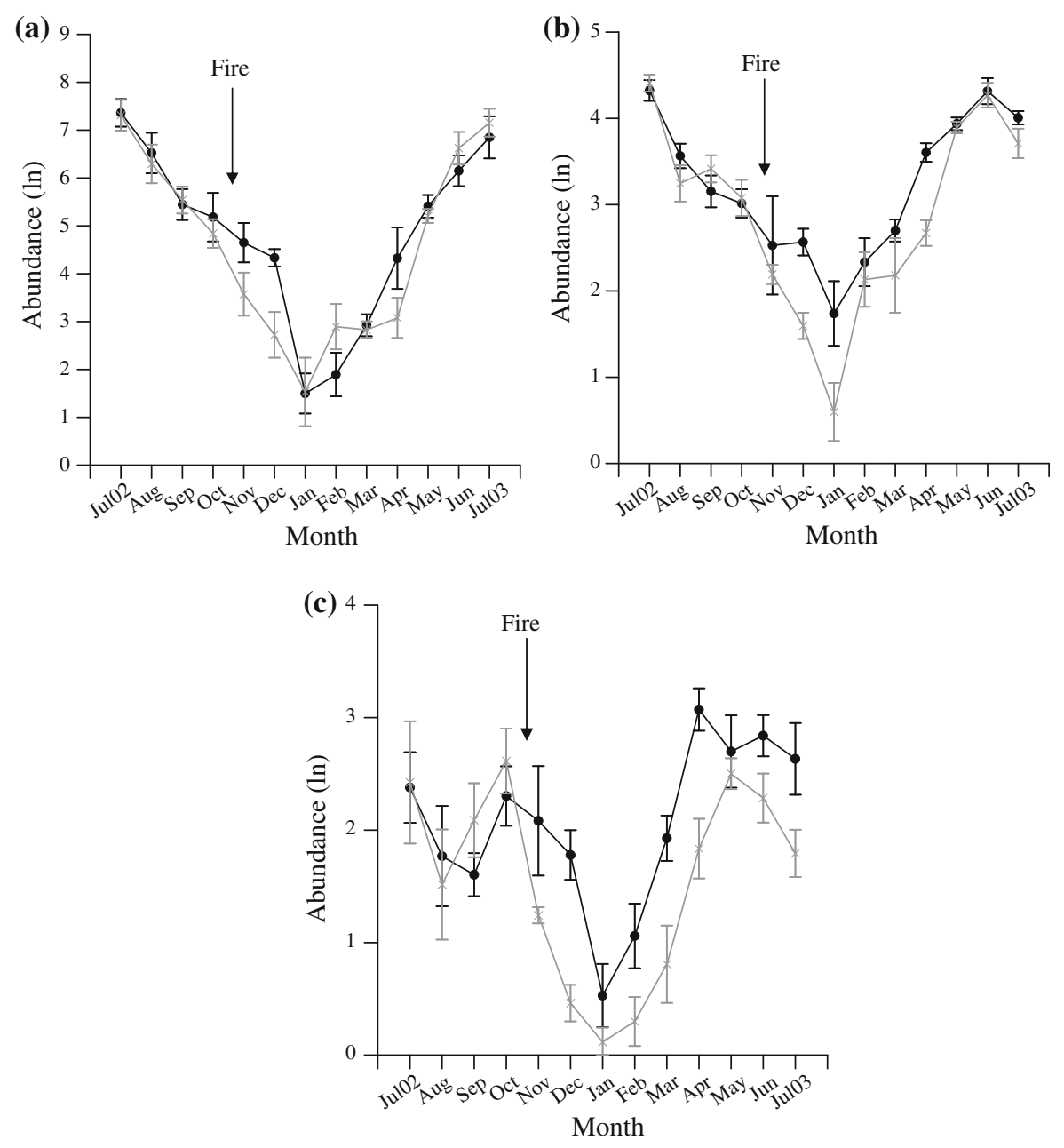

$(F=3.65, \mathrm{df}=1, \quad P=0.085)$, again occurring most notably in the second (December) and third (January) postburn collections $(F=5.84, \quad \mathrm{df}=1, \quad P=0.036$ and $F=10.48, \mathrm{df}=1, P=0.009$ respectively). Interestingly, the only group to exhibit an increase in abundance in burn plots was the Funnel Web group immediately after the burn $(F=13.67, \mathrm{df}=1, P=0.004)$. However, interpretation of this must be made cautiously, since neither burn nor burn-by-month interaction was significant. The Diurnal Stalk and Diurnal Pursuit hunting guilds were least affected by autumn prescribed fires.

\section{Canonical correspondence analysis}

The Monte Carlo tests demonstrated that the relationship between ant species abundance and environmental and vegetation variables was higher than expected by chance for all three axes $(P=0.001, P=0.037$, and $P=0.002$ respectively). Axis 1 explained $19.6 \%$ of the variance in the ant species data with the environmental data, with Axes 2 and 3 contributing 5.7 and $4.7 \%$ respectively (explaining a total of $30 \%$ of the variance). The CCA biplot (Fig. 2) reflects the spatial distribution of ant species, pitfall traps, and the contribution of environmental and vegetation related variables. The length of the vectors signifies the relative contribution of that variable to species composition, while the direction shows its contribution to differences between plots. Seven of the twelve environmental and vegetation variables strongly contributed to the variance in species composition (Fig. 2). Five ant species, the majority of which are omnivores (Tapinoma sessile, Pheidole hyatti, Leptothorax nevadensis, Solenopsis molesta and Brachymyrmex depilis) were strongly positively associated with height of the herbaceous layer and \% cover of non-native forbs. In contrast, two seed-harvesters Messor andrei and M. chicoensis, and one omnivore, Camponotus semitestaceus, preferred areas with lower herbaceous and non-native forb cover - exhibiting positive associations with $\%$ bare ground, $\%$ rock cover, and plant species richness. Pheidole creightoni / P. californica was positively associated with distance from oak and greater $\%$ cover of native forbs. In contrast, the ordination axes using spider group abundance explained a lower amount of the variance in species data $(6.2,5.9$, and $2.1 \%$ respectively for 
Fig. 2 CCA ordination of transformed abundances of ant species from control pitfall traps collected in June and July 2003 at the Dye Creek Preserve, northern California, following late season (autumn) prescribed fires conducted in October 2002. Circles (black) represent pitfall traps and vectors reflect the relationship with environmental variables: $O K$ distance to oak, $B$ $\%$ bare ground, $R \%$ rock, $W \%$ wood, $C \%$ cow pat, $H H$ height of herbaceous layer, $S P$ plant species richness, IF \% cover of invasive and non-native forbs, $N F \%$ cover of native forbs, and $N G \%$ cover native grasses. Species are indicated by ' + ' and species codes represent first 3 letters of species and genus, listed in Table 1

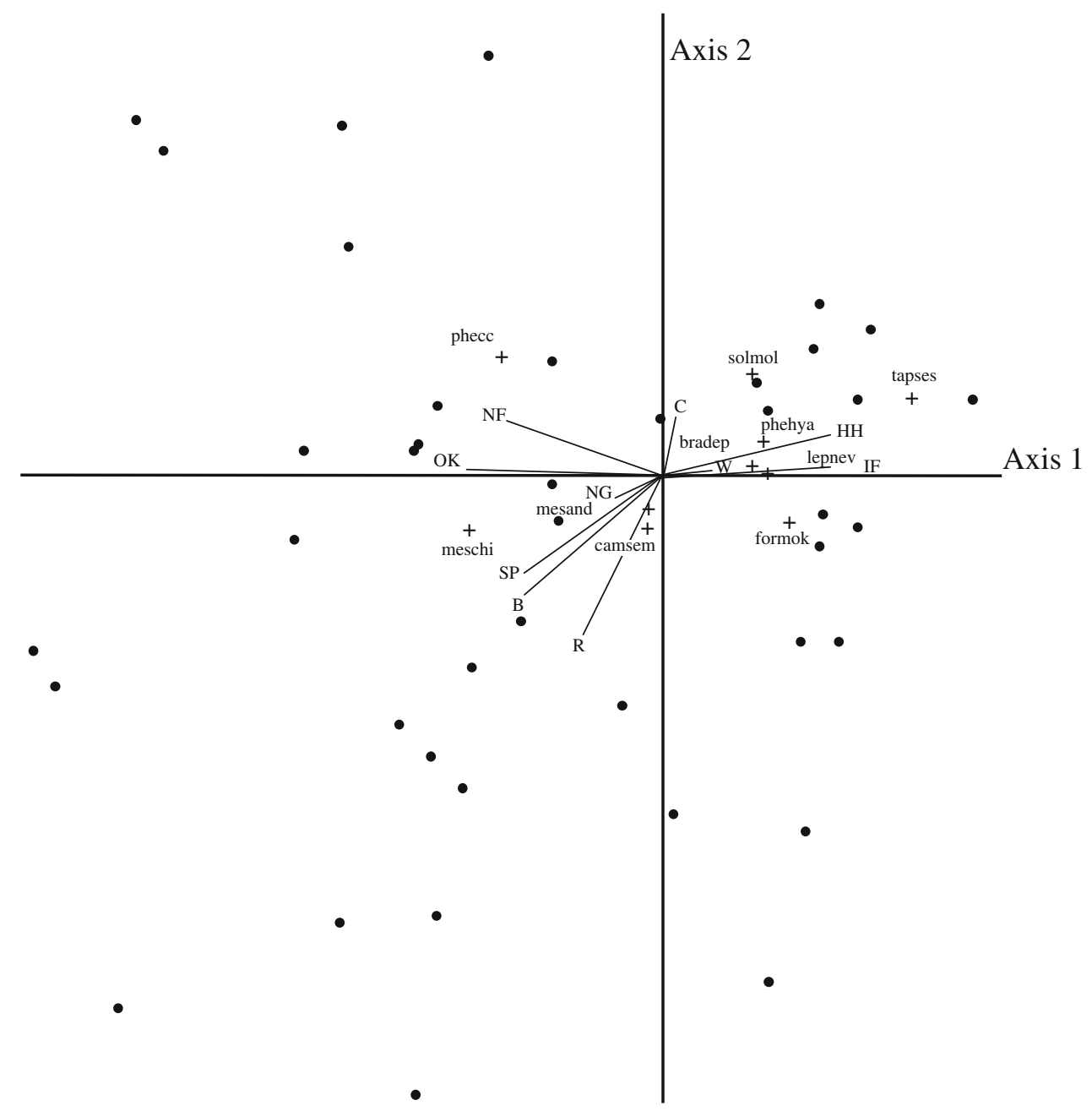

The response of ant functional groups can be interpreted to some extent from a physiological context. The immediate post-fire decline in seed-harvester abundance might be explained by the fact that the key seed-harvesters in this ecosystem are strongly thermophilic, with foraging activity levels of workers being regulated by temperature. Exposed burn plots during the cooler autumn and winter months, devoid of herbaceous cover and litter present more extreme microenvironmental conditions and likely unattractive foraging grounds for seed-harvesters (Andersen and Yen 1985; Neumann 1991). Support for this interpretation is provided by the ordination associations of key seed-harvesters in the summer months, e.g., Messor chicoensis and $M$. andrei, with greater bare ground and rock cover, and lower herbaceous vegetation (Fig. 2).

The decline in total spider abundance, and also the Diurnal Ambush and Nocturnal Running groups, did not occur in the immediate post-burn collections but rather the second and third collections-a phenomenon observed in other fire experiments (e.g., Reichert and Reeder 1970). This delayed response suggests that spiders often survive 
the burn in situ by seeking refuge under rocks and wood, and indeed benefit from a post-fire spike in food as dead and damaged prey are consumed. A decrease in their abundance might then result from decreased prey levels, emigration, moving more deeply in the soil, or through mortality under changed ambient conditions (Reichert and Reeder 1970). Mortality seems to be the most plausible explanation considering the importance of herbaceous vegetation and litter to many spiders (Moretti et al. 2002; Post and Reichert 1977). In addition a significant post-fire decline in potential prey such as Coleoptera, and the seasonal decline in Orthoptera and Thysanura which disappeared completely over the winter (Underwood, unpub. data), undoubtedly accentuated the effects of burning. The Diurnal Ambush group, which employs a sedentary, sitand-wait hunting strategy, exemplifies the problems encountered in post-fire conditions. This group displayed a sustained decrease in burn plots (Fig. 1c) that is consistent with several other studies (Niwa and Peck 2002; Warren et al. 1987). Although spiders can endure long periods of starvation when prey capture is low, this group can either continue to sit-and-wait or move to a more productive environment (Wise 1993). Relocating, however, must be offset by the risk of increased exposure to predatorsbirds, for example, have been observed and experimentally shown to be major predators of over-wintering spiders (e.g., Hogstad 1984; Reichert and Hedrick 1990).

The findings from this study demonstrate that ant and spider responses to a late season fire in an oak woodland appear to be relatively modest and short-term, even though the previous absence of fire in the experimental plot area might have suggested more severe effects. In contrast, our study examining the impacts of early season spring burns in a similar habitat (Underwood and Christian 2009) found seed-harvesters increased significantly in burned plots after one year. This difference might emphasize the historical role of fire in oak woodland ecosystems, with invertebrates accordingly fire adapted and resilient, although longer term studies need to be conducted since indirect fire effects, such as nutrient cycling, might take several years to have an effect (Whelan 1995). Nevertheless, the results from this study are encouraging given that the project was developed to provide practical scientific guidance on the effects of reintroducing fire into the landscape. Conservation managers at the preserve now have reasonable evidence that the ant and spider communities will continue to function normally in the face of late season fires.

Acknowledgments We thank R. Reiner, P. Hujik, and M. Reynolds at The Nature Conservancy for support and logistical help, and C. Schoendienst and CDF crews for conducting the prescribed fires. We gratefully acknowledge manuscript reviews provided by P. Cranston, S. Ustin, and V. Russell and Alan Andersen for comments on a previous version. We thank R. Klinger for discussions on data analysis and D. Burge for laboratory and field help. Financial support for this study was provided by The Nature Conservancy's Schlinger project.

Open Access This article is distributed under the terms of the Creative Commons Attribution Noncommercial License which permits any noncommercial use, distribution, and reproduction in any medium, provided the original author(s) and source are credited.

\section{References}

Abbott I (1984) Changes in the abundance and activity of certain soil and litter fauna in the Jarrah forest of Western Australia after a moderate intensity fire. Aust J Soil Res 23:463-469

Abbott I, Burbidge T, Strehlow K, Mellican A, Wills A (2003) Logging and burning impacts on cockroaches, crickets and grasshoppers, and spiders in Jarrah forest, Western Australia. Forest Ecol Manag 174:383-399

Alonso LE (2000) Ants as indicators of diversity. In: Agosti D, Majer JD, Alonso LE, Schultz TR (eds) Ants. Standard methods for measuring and monitoring biodiversity. Smithsonian Institution Press, Washington DC, pp 80-88

Andersen AN (1991) Responses of ground-foraging ant communities to three experimental fire regimes in a savanna forest of tropical Australia. Biotropica 23:575-585

Andersen AN, Yen AL (1985) Immediate effects of fire on ants in the semi-arid mallee region of northwestern Victoria. Aust J Ecol 10:25-30

Bailey AW, Poulton CE (1968) Plant communities and environmental relationships in a portion of the Tillamook burn, northwestern Oregon. Ecology 49:1-13

Baker WL (1994) Restoration of landscape structure altered by fire suppression. Conserv Biol 8:763-769

Barbour M, Pavlik B, Drysdale F, Lindstrom S (1993) California's changing landscapes: diversity and conservation of California vegetation. California Native Plant Society, Sacramento

Biswell HH (1989) Prescribed fire: California wildland vegetation management. University of California Press, Berkeley

Burge DO (2005) Taxonomy, biology, and distribution of seed harvesting ants in the Pheidole californica complex (Hymenoptera: Formicidae). J Hymenopt Res 14:137-150

Curtis JT, Partch ML (1948) Effect of fire on the competition between blue grass and certain prairie plants. Am Midl Nat 39:437-443

Hogstad O (1984) Variation in numbers, territoriality and flock size of a Goldcrest Regulus population in winter. Ibis 126:296-306

Hölldobler B, Wilson EO (1990) The ants. Belknap Press, Cambridge

Jackson GP, Fox BJ (1996) Comparison of regeneration following burning, clearing or mineral sand mining at Tomago, NSW. II. Succession of ant assemblages in a coastal forest. Aust $\mathrm{J}$ Ecol 21:200-216

Jepson WL (1910) The silva of California. Memoirs of the University of California. University Press, Berkeley

Kaspari M (2000) Primer on ant ecology. In: Agosti D, Majer JD, Alonso LE, Schultz TR (eds) Ants. Standard methods for measuring and monitoring biodiversity. Smithsonian Institution Press, Washington DC, pp 9-24

Klinger RC, Messer I (2000) The interaction of prescribed burning and site characteristics on the diversity and composition of a grassland community on Santa Cruz Island, California. In: Galley KE, Wilson TP (eds) Proceedings of the invasive species workshop: the role of fire in the control and spread of invasive species. Miscellaneous Publication, Tall Timbers Research Station, Tallahassee, pp 66-80 
Lal R (1988) Effects of macrofauna on soil properties in tropical ecosystems. Agric Ecosyst Environ 24:101-116

Lewis HT (1995) Patterns of Indian burning in California: ecology and ethno-history. In: Blackburn TC, Anderson K (eds) Before the wilderness: environmental management by Native Californians. Ballena Press, Menlo Park, pp 55-116

Majer JD (1983) Short-term responses of soil and litter invertebrates to a cool autumn burn in Jarrah (Eucalyptus marginata) forest, in Western Australia. Pedobiologia 26:229-247

Martínez-Abrain A (2007) Are there any differences? A non-sensical question in ecology. Acta Oecol 32:203-206

McCune B, Mefford MJ (1999) PC-ORD. Multivariate analysis of ecological data. MjM Software Design, Gleneden Beach

McIver JD, Parsons GL, Moldenke AR (1992) Litter spider succession after clear-cutting in a western coniferous forest. Can $\mathbf{J}$ Forest Res 22:984-992

Melbourne BA (1999) Bias in the effect of habitat structure on pitfall traps: an experimental evaluation. Aust J Ecol 24:228-239

Moretti M, Conedera M, Duelli P, Edwards PJ (2002) The effects of wildfire on ground-active spiders in deciduous forests on the Swiss southern slope of the Alps. J Appl Ecol 39:321-336

Neumann FG (1991) Responses of litter arthropods to major natural or artificial ecological disturbances in mountain-ash forest. Aust J Ecol 16:19-32

Niwa CG, Peck RW (2002) Influence of prescribed fire on carabid beetle (Carabidae) and spider (Araneae) assemblages in forest litter in southwestern Oregon. Environ Entomol 31:785-796

Parsons DJ, van Wagtendonk JW (1996) Fire research and management in the Sierra Nevada national parks. In: Halvorson W, Davis GE (eds) Science and ecosystem management in the national parks. University of Arizona Press, Tucson, pp 25-48

Pearse AS (1943) Effects of burning over and raking off litter on certain soil animals in the Duke forest. Am Midl Nat 29:406-424

Peterson DW, Reich PB (2001) Prescribed fire in oak savanna: fire frequency effects on stand structure and dynamics. Ecol Appl 11:914-927

Post WM, Reichert SE (1977) Initial investigation into the structure of spider communities. J Anim Ecol 46:729-749

Reichert SE, Hedrick V (1990) Levels of predation and genetically based anti-predator behaviour in the spider, Agelenopsis aperta. Anim Behav 40:679-687

Reichert SE, Reeder WG (1970) Effects of fire on spider distribution in southwestern Wisconsin prairies. In: Zimmerman JH (ed)
Proceedings of the 2nd Midwest Prairie Conference. University of Wisconsin, Madison, pp 73-90

SAS Institute Inc (1999) SAS/STAT user's guide. Ver 8, 4th edn. SAS Institute, Cary

ter Braak CJF (1995) Ordination. In: Jongman RHG, ter Braak CJF, van Tongeren OFR (eds) Data analysis in community and landscape ecology. Cambridge University Press, New York, pp 91-173

The Nature Conservancy (2000) Gray Davis Dye Creek Preserve five year management plan (July 1, 2000-June 30, 2005). Unpublished report

Trueman JWH, Cranston PS (1994) An evaluation of some methods of rapid biodiversity assessment for estimating arthropod diversity. CSIRO Division of Entomology, Canberra

Uetz GW (1979) The influence of variation in litter habitats on spider communities. Oecologia 40:29-42

Uetz GW, Unzicker JD (1976) Pitfall trapping in ecological studies. J Arachnol 3:101-111

Underwood EC, Christian CE (2009) Consequences of prescribed fire and grazing on grassland ant communities. Environ Entomol 38:325-332

Vanderwoude C, Andersen AN, House APN (1997) Ant communities as bio-indicators in relation to fire management of spotted gum (Eucalyptus maculata Hook.) forests in south-east Queensland. Mem Mus Victoria 56:671-675

von Ende CN (2001) Repeated-measures analysis: growth and other time-dependent measures. In: Scheiner SM, Gurevitch J (eds) Design and analysis of ecological experiments. Oxford University Press, New York, pp 134-157

Warren SD, Scifres CJ, Teel PD (1987) Response of grassland arthropods to burning: a review. Agric Ecosyst Environ 19:105130

Whelan RJ (1995) The ecology of fire. Cambridge University Press, Cambridge

Whelan RJ, Langedyk W, Pashby AS (1980) The effects of wildfire on arthropod populations in Jarrah-Banksia woodland. West Aust Nat 14:214-220

Whitford WG (1978) Structure and seasonal activity of Chihuahua desert ant communities. Insect Soc 25:79-88

Wise DH (1993) Spiders in ecological webs. Cambridge University Press, Cambridge 